\title{
Карамзин во Франции
}

\author{
Антон Олегович Дёмин \\ Институт русской литературы РАН (Пушкинский дом) \\ anton demin@mail.ru
}

Nikolaï Karamzin en France. L'image de la France dans les Lettres d'un voyageur russe [Nikolai Karamzin in France. The Image of France in the Letters of a Russian Traveler], sous la direction de Rodolphe Baudin (Paris: Institut d'études slaves, 2014), 228 p., ill., ISSN 0078-9976, ISBN 978-2-7204-0523-5

Сборник научных трудов Карамзин во Франции: Образ Франции в 'Письмах русского путешественника' появился в 2014г. Издание подготовлено парижским Институтом славяноведения (Institut d'Etudes Slaves) в сотрудничестве со Страсбургским университетом и Группой восточных, славянских и новогреческих исследований Страсбургского университета (GEO EA 1340) на его базе.

В основу публикации положены материалы международной конференции, организованной в июне 2010 г. Группой. В конференции, а затем и в сборнике приняли участие известные специалисты из России, Франции, Англии, США, Австрии, Нидерландов и Болгарии, занимающиеся исследованием жизни и творчества Карамзина, а также русской историей рубежа XVIII-XIX вв. К одиннадцати статьям на основе докладов добавлены четыре работы, дополняющие их содержание, три из них ранее уже были опубликованы. Книга имеет нарядную обложку и украшена многочисленными иллюстрациями.

Стоит особо подчеркнуть важную роль доцента Страсбургского университета Р. Бодэна в осуществлении этого начинания. Он организовал конференцию и взял на себя составление и редактирование сборника, предпослал ему развернутое информативное предисловие, перевел для него ряд материалов с русского и английского языков.

Актуальность сборника трудов, посвященных французской части Писем русского путешественника, обоснована в предисловии. Путешествие Карамзина по Франции и описание его в книге являются важнейшей частью его европейского маршрута и повествования о нем. Однако в течение долгого времени темы исследований, посвященных отношению Карамзина к Франции, ограничивались рассмотрением его взглядов на Великую французскую буржуазную революцию. Между тем, начиная с 1960-х гг. в разных странах появлялись работы, где подробно освещались английские, швейцарские, немецкие эпизоды Писем во всем многообразии их содержания. Лишь во второй половине 1990-х гг. серия публикаций Ж. Брейяра (Jean Breuillard) под общим заглавием “Карамзин и Франция” положила начало новому подходу к теме, существенно расширяющему привлекаемый материал и спектр интерпретаций. Р. Бодэн, ученик и друг Брейяра, последовал за ним в этом новом для французской славистики понимании Писем русского путешественника. Результатами его труда стала организованная в 2010 г. упомянутая выше конференция и выпущенная в следующем году монография Николай Карамзин в Страсбурге: русский писатель-путешественник в революционном Альзасе (1789). 2011 г. ознаменовался также прискорбным событием - безвременной кончиной Ж. Брейяра, 
бывшего к тому времени руководителем Института славяноведения и журнала Revue des études slaves. Сборник статей Карамзин во Франции стал данью памяти ученого, это отмечено на шмуцтитуле, в книгу включен отрывок из ранее публиковавшейся статьи Брейяра “Карамзин и Франция” под заголовком “Французская культура как практика.” Издание позволяет наглядно убедиться, насколько тесно переплетены история науки и человеческие отношения.

Совокупность публикаций, представленных в книге, преследует цель дать разностороннее представление о путешествии Карамзина по Франции и об отражении его в Письмах. Пятнадцать материалов, предваряемых вступлением от редактора “Карамзин во Франции: между страной воображаемой и действительной,” объединены в пять тематических групп.

Вопросы, освещаемые во вступительной статье, касаются определения типа путешествия, совершаемого Карамзиным, его маршрута, выбора осматриваемых предметов и взгляда на них, представления их в тексте. Осознание сложной связи между реальной Францией, Францией, увиденной под определенным углом зрения, и описанной в книге, помогает открыть несколько разных стран под этим именем в тексте Карамзина.

Первый раздел статей, “Языки,” включает две работы, посвященные лингвистическим вопросам. Статья Г. Хаммарберг “Карамзин во Франции: дискурс путешествия и двойной дейксис" отталкивается от основной характеристики Писем, сформулированной Ю. М. Лотманом и Б. А. Успенским: двойственности образа автора, обращающегося к двойной аудитории, - к читателю русскому и читателю европейскому. Г. Хаммарберг предполагает анализировать функционирование терминов “автор,” “Карамзин” и особенно “читатель” как исключительно текстовых реалий и показывает, как взаимное познание народов, являющееся основным содержанием Писем, реализуется в книге с помощью метафоры “чтения" и “перечитывания,” нередко овеществляемой. Опыт конкретных лингвистических наблюдений предлагает работа К. Бракенье "Использование французского языка в Письмах русского путешественника." Автор анализирует конкретные случаи заимствований, распределенные по семантическим полям, способы внесения иноязычного материала в русский текст Писем (курсив, сноски, глоссирование), передачу имен собственных в переводе или транслитерации и функционирование топонимов и заголовков. Особые главки посвящены включению в основной текст иноязычных цитат и оформлению французских вкраплений в авторскую речь и в речь персонажей.

Раздел “Места" включает статьи о географических пунктах во Франции, посещенных и упомянутых Карамзиным в Письмах. Его открывает работа Р. Бодэна “Карамзин и Страсбургский собор,” которая до этого уже дважды была опубликована в 2011 г., как отдельно, так и в составе книги Николай Карамзин в Страсбурге. Широко привлекаемый исторический и искусствоведческий материал позволяет автору назвать литературные источники описания собора в Письмах, а также осветить вопросы вовлеченности Карамзина в европейское пробуждение интереса к архитектурной готике. Статья "Образ Парижа в Письмах русского путешественника" О. Б. Кафановой дает беглый обзор страниц книги Карамзина, посвященных главной европейской столице на его пути, ее мифологии, топонимике, духовной и интеллектуальной жизни. А. Л. Зорин в статье “Кале, или Путешественник на 
границах" упоминает многочисленные в тексте Писем ситуации пересечения границ между государствами, землями, заметки о многообразии национальных характеров, встречаемых “Путешественником" Карамзина. Этот материал положен в основу рассуждения о преимуществах духовного, культурного, политического и чувственного опыта, обусловленного, с одной стороны, наличием ясно очерченных границ и осознаваемым существованием “другого,” а с другой, - легкостью их пересечения, возможной в пространстве единой культуры.

Логическим продолжением "Мест" служат “Встречи.” Статья А. Вачевой “Француженки в Письмах русского путешественника" предлагает обзор женских образов, возникающих на страницах путевых записок Карамзина. С ними связаны рассуждения о любви, бескорыстной привязанности, чувстве собственного достоинства, семейственных добродетелях, формирующих сентиментальный этический идеал, и размышления о глубоком нравственном кризисе, постигшем французское общество в эпоху Революции. В работе Г. Леманн-Карли "Карамзин и Пьер-Шарль Левек: Суждения Карамзина о Петре Великом в свете суждений Левека” внимание уделено продолжительному историко-философскому диалогу сначала молодого русского литератора и поклонника европейской культуры, а затем маститого историографа, умудренного опытом революции и войны, с одним из самых авторитетных историков Европы о ключевом периоде для России, - эпохе правления Петра I. Диалог этот, начатый чтением Российской истории Левека, получивший продолжение во время личного знакомства в Париже в 1790 г., завершился лишь во время создания Истории государства российского. Небольшой по объему, но весьма содержательный материал Е. В. Карповой “Карамзин в лионской мастерской Жозефа Шинара" был ранее опубликован в двадцать пятом сборнике российской академической серии XVIII век на русском языке, однако более чем полезен для франкоязычного читателя, поскольку содержит аргументированное и убедительное отождествление неназванного скульптора, встреченного Карамзиным в Лионе, с Ж. Шинаром (Chinard, 1756-1813). Ранее в этой фигуре видели русского ваятеля И. М. Козловского. Раздел завершает очерк Р. Бодэна “Образ французского эмигранта в Письмах русского путешественника." Обозрение эпизодов Писем, где появляются фигуры французских эмигрантов, позволяет исследователю высказать обоснованную точку зрения на отношение Карамзина к Французской революции, то есть по наиболее обсуждавшемуся вопросу в исследовании французской части Писем, а также проследить весьма важную историко-литературную перспективу. “Эмигрант, общественный тип, быстро сделался ключевой литературной фигурой на закате эпохи Просвещения, поскольку предвозвестил романтическую фигуру изгнанника. В этих условиях кажется интересным рассмотреть, был ли чувствителен Карамзин к появлению этого нового вымышленного персонажа и литературного течения, ядром которого он стал," - формулирует свою задачу исследователь. Анализ избранного материала позволяет ему подтвердить отрицательное отношение писателя к Революции и к ее последствиям в жизни отдельных личностей, а также показать, что в изображении эмигранта Карамзин на несколько лет опередил немецкую и французскую романную традицию.

Раздел “Практики” содержит исследования форм культурного опыта, нашедших отражение в книге Карамзина. В статье Т.И.Смоляровой “'В сияющий Марли...': Несколько замечаний к письму 122” сделана попытка широкого культурологического и 
литературного комментария к эпизоду посещения “Путешественником” сада Марли под Парижем, приводимого в связи с этим отрывка из поэмы Ж. Делиля “Сады” в переводе Карамзина и упоминания знаменитой гидравлической машины. Эпизод дает автору повод изложить историю гидравлической машины и ее упоминаний в современной Карамзину литературе, дать очерк французской описательной натурфилософской поэзии XVIII в. и трактовки в ней понятия возвышенного, а также коснуться теории художественного перевода. М. Штембергер предлагает очерк "Карамзин в театрах Франции: Театр, театральность и революция в Письмах русского путешественника." Анализируя упоминания о лионской и парижской театральной жизни эпохи Революции в политическом ключе, автор размышляет о роли театра как предмета поэтологических рассуждений, а также о театральности как парадигме общества, политическая и культурная жизнь которого воспринимается “Путешественником" в сценических терминах. Раздел завершает уже упомянутый выше отрывок из статьи Ж. Брейяра “Французская культура как практика,” где рассматриваются отрывки Писем, посвященные повседневной жизни в Париже: кафе, рестораны, салоны, театры как места и способы общения и создания подлинно общественной жизни, доступной всем гражданам и совместно творимой ими.

В заключительном, пятом разделе, сборника, “Рассуждения," затрагиваются темы русской галломании и галлофобии в связи с творчеством Карамзина, а также роли его наследия в духовном и политическом формировании декабристов. Короткое выступление И. Клейна "Карамзин - русский европеец во Франции" противопоставляет характерную для второй половины XVIII в. повышенную ксенофобию россиян (под определение ксенофобии попадает борьба с последствиями бироновщины в царствование Елизаветы Петровны, выступления Фонвизина и Новикова против крайних проявлений галломании, а также не слишком почтительное отношение россиян к туркам в период русско-турецких войн 1760-х-1790-х гг.) и просвещенную терпимость Карамзина-путешественника и призывает к изучению европейских корней его позиции. Н.Д. Кочеткова в работе “Карамзин между галломанами и галлофобами” дает широкую панораму острых полемических суждений о Письмах и личности их автора, появившихся в России тотчас после возвращения Карамзина из-за границы и обнародования его труда. Наконец, А. В. Семенова в работе “Восприятие Карамзиным Французской революции и русская либеральная традиция начала XIX в.” дает сжатый очерк фактов и суждений, свидетельствующих о существенном влиянии опыта Французской буржуазной революции на российское революционное движение от офицерских заговоров против Павла I до Октябрьской революции 1917 г. Письма Карамзина являются важным источником сведений и для историка самих парижских событий, и для того, кто занят воссозданием и осмыслением их воздействия на русское общество и государство.

Сборник статей Карамзин во Франции является международным и междисциплинарным, объединяет под своей обложкой работы ученых из разных стран и разных исследовательских школ, занимающихся не только историей литературы, но также историей искусств, политических учений и языка. Он посвящен актуальной проблематике изучения французской части европейского путешествия Карамзина и его представления в Письмах русского путешественника.

Благодарный читатель, однако, будет вынужден смириться с некоторыми недостатками редактуры. На спинке обложки говорится о четырнадцати 
представленных материалах, хотя в действительности их пятнадцать, если не считать развернутую вступительную статью, преследующую отнюдь не только редакционноинформативные цели. В книге, к сожалению, отсутствует именной указатель, который существенно упростил бы ориентацию в ее тексте. Унификация библиографических отсылок вызывает некоторое недоумение. С одной стороны, на протяжении всего текста действует отсылка к ранее упоминавшимся изданиям с помощью начальных слов их названий и пометки op. cit., так что приходится немало потрудиться, чтобы отыскать первое, полное, описание источника на предыдущих страницах, иногда в довольно далеко отстоящей статье. С другой, - почти в каждой статье в одном из первых примечаний дается полное описание издания Писем в серии “Литературные памятники” с последующим его сокращением, что представляется излишним. Неясно также, почему в отличие от всех остальных авторов К. Бракенье ссылается не на это издание, а на двухтомник сочинений Карамзина 1964 г. С бо̀льшим вниманием следовало бы отнестись к унификации библиографических описаний. Ср., например, описание сборника XVIII век на с. 138 (сноска 3) и на с. 169 (сноска 20). В обоих случаях в разделе сведений об издательстве должно быть: Nauka. Встречается также разнобой в оформлении авторских глосс при цитировании: с. 59 (сноска 5): [le soulignement en gras est de moi - CB] и с. 170 (сноска 21): C'est moi qui souligne (T.S.). Причем во втором случае в соответствующей длинной стихотворной цитате нет выделенного фрагмента.

За этими мелкими “косметическими” замечаниями естественно, стоит желание видеть в замечательной работе Группы восточных, славянских и новогреческих исследований Страсбургского университета и особенно доцента Р. Бодэна не только продуманность научной концепции, но и высокий уровень ее издательского воплощения. За последние полвека изучение жизни и творчества Карамзина превратилось в целую отрасль исторической науки, представленное множеством направлений, имен и публикаций. Искренне хотелось бы пожелать, чтобы труды, предпринимаемые в продолжение замечательных изысканий Ж. Брейяра и посвященные столь перспективной и многообещающей области, как связи Карамзина с французской культурой, всегда отличались высоким качеством исполнения. 